ПРОЦЕС ПРИЙНЯТТЯ РІШЕННЯ ПРО КУПІВЛЮ ІНДИВІДУАЛЬНИМ СПОЖИВАЧЕМ: СОЦІОЛОГІЧНИЙ АСПЕКТ

\title{
THE DECISION-MAKING PROCESS FOR THE PURCHASE OF THE INDIVIDUAL CONSUMER: THE SOCIOLOGICAL ASPECT
}

УДК 303.4:316.334.2

DOI https://doi.org/10.32843/26635208.2020.15.3

щерба O.I.

к.соціол.н., доцент, докторант відділу історії

та теорії соціології

Інститут соціології

Національної академії наук України
У статті розглянуто теоретичні основи дослідження науковцями прочесу прийняття рішення про купівлю індивідуальними споживачами. Особливу увагу приділено соціологічним чинникам даного процесу. Проаналізовано фрази прочесу прийняття рішень споживачем: відчуття потреби, пошук альтернатив, оцінка альтернатив, рішення про купівлю, відчуття після покупки. Виділено типи споживачів залежно від рівня ангажованості споживача у процес пошуку інсрормації про товар, такі як когнітивно ангажований та неангажований. Наголошено на тому, що процес споживання - це, з одного боку, конкретна фрізична поведінка, що піддається спостереженню (купівля товару), з іншого - психічний процес, який неможливо безпосередньо спостерігати (прийняття рішення). Описано стратегії прийняття рішення споживачем щодо купівлі, такі як стратегія переваги позитивних характеристик, об'єднювальна, альтернативна, лексикографрічна, стратегія домінування та псевдодомінування, стратегія максимізаиії додаткової корисності МДК (стратегія компенсації). Виокремлено умови впливу ситуації на прийняття рішення про придбання товару, такі як фрізичні, суспільні, умови, що випливають із сутності ситуації, умови, що пов'язані з часом, та умови, що супроводжують акт самої покупки. Визначено поняття післякупівельного когнітивного дисонансу, який з'являється у споживача у разі незадоволеності здійсненою покупкою. Подано основні типи реакції споживачів на незадоволення від товару, такі як відхід, словесна реакція та відсутність будь-якої реакції. Підкреслено, що цивілізаційні, технологічні та культурно-соціальні зміни також впливають на зміни типового прочесу прийняття рішення про купівлю. Зроблено висновок, що на тлі викладених міркувань можна стверджувати про важливість дослідження прийняття споживачем рішення про купівлю та чинників, які на даний процес впливають.

Ключові слова: поведінка споживача, відчуття потреби, рішення про купівлю, від- чуттяя після покупки, стратегії прийняття рішення.

The article considers the theoretical foundations of research by scientists on the purchase decision-making process by individual consumers. Particular attention is paid to the sociological factors of this process. The phases of the consumer decision-making process are analyzed: the feeling of need, the search for options, the evaluation of options, the decision to buy, the feeling after the purchase. The types of consumers depending on the level of consumer involvement in the process of finding information about the product, such as cognitively engaged and non-engaged, are identified. It is emphasized that the process of consumption is a two-way concept - on the one hand - it is a specific, physical behavior that can be observed (purchase of goods); on the other hand, it is a mental process that cannot be directly observed (decision-making). The article describes consumer decision-making strategies for purchasing, such as the strategy of advantage of positive characteristics, unifying, alternative, lexicographic, strategy of dominance and pseudo-dominance, the strategy of maximizing the additional usefulness MAU (compensation strategy). The conditions of the situation's influence on the decision to purchase goods, such as physical, social, conditions arising from the nature of the situation, conditions related to time and conditions accompanying the act of purchase are identified. The concept of post-purchase cognitive dissonance, which appears in the consumer when dissatisfied with the purchase, is defined. The main types of consumer reaction to dissatisfaction with the product, such as withdrawal, verbal reaction and the absence of any reaction. It is emphasized that civilizational, technological and cultural-social changes also affect changes in the typical purchase decision-making process. It is concluded that against the background of the above considerations, it can be argued about the importance of the study of consumer decision-making on the purchase and the factors that affect this process.

Key words: consumer behavior, feeling of need, purchase decision, feeling after purchase, decision-making strategies.
Постановка проблеми. У діяльності підприємств надзвичайно важливо зрозуміти механізми поведінки споживачів, включаючи детермінанти прийняття рішень. Підприємці повністю усвідомлюють, що продажі не стаються випадково. Розуміння та аналіз поведінкової системи є, однак, складним процесом. Причина полягає у складності площин, у яких розглядається поведінка споживачів, і точок зору, які можна врахувати під час розгляду. Економічний і соціальний розвиток держав зосереджується навколо людини; вона $є$ творцем багатьох процесів, розвивається і функціонує у багатьох вимірах. Соціологія вивчає людину як суспільну одиницю, яка живе, працює, розвивається, комунікує з іншими людьми та, серед іншого, акумулює ресурси для задоволення власних потреб. Отримані в результаті цього знання допомагають зрозуміти та передбачити поведінку споживача, а також шлях, який проходить індивід від виникнення у нього незадоволеної потреби 
до прийняття рішення про купівлю товару або користування послугою, які можуть задовольнити дану потребу. Цим і зумовлена актуальність теми наукового дослідження.

Аналіз останніх досліджень і публікацій. Дослідження проблем, пов'язаних із процесом прийняття рішення про купівлю споживачами, є об'єктом дослідження таких учених, як Р. Блекуел, П. Мініард, Дж. Енджел, Ф. Котлер, Дж. Армстронг, Дж. Антонідс, В. Ван Раай, Дж. Фоксел, Р. Голдсміт, Л. Рудницький, Л. Гарбарський, А. Хіршман, Д. Лаудон, А. Делла Бітта, С. Смичек, І. Сова, А. Яхніс, М. ЯносьКресло, А. Фальковський, Т. Тишка та ін.

Постановка завдання. Метою статті $€$ соціологічне обґрунтування процесу прийняття рішення про купівлю індивідуальним споживачем.

Виклад основного матеріалу дослідження. Поведінка $€$ одним із найпоширеніших проявів людської діяльності. Вона зумовлена як минулим, так і передбаченням майбутніх подій. Проявляється у діях, спрямованих на досягнення конкретного остаточного стану [9, с. 163]. Поведінка споживачів може включати розумові та фізичні дії, а також їхні мотиви та причини. Ці дії пов'язані з вибором, купівлею, використанням, утримуванням та утилізацією товару (цикл споживання), можуть виникати як у осіб, так і у малих групах. Вони дають змогу споживачеві функціонувати, досягати цілей та реалізовувати цінності, завдяки яким він може досягти задоволення та процвітання. Звідси випливає, що процес споживання є двостороннім поняттям: з одного боку - це конкретна, фізична поведінка, що піддається спостереженню (купівля товару), з іншого - психічний процес, який неможливо безпосередньо спостерігати (прийняття рішення) [3].

Споживча поведінка покупців у літературі розглядається поряд із поведінковими перспективами та досвідом із погляду прийняття рішень (споживач у процесі вирішення проблем) [14, с. 48]. Щодня індивід приймає незліченну кількість рішень: одні приймаються автоматично, не замислюючись, інші потребують коротшої або тривалішої рефлексії. Деякі рішення стосуються тривіальних та повсякденних питань, таких як купівля їжі, миючих засобів, поповнення рахунку у мобільному телефоні, оплата комунальнихпослуг, тане маютьсерйозних наслідків. Деякі є серйознішими, вимагають довшого роздумута більших фінансовихвитрат, наприклад придбання автомобіля або відпочинкової закордонної подорожі. Ще інші мають наслідки на все життя (шлюб, робота), тому споживач довго думає, перш ніж приймати їх.

Рішенням називається вибір дії з двох або більше доступних альтернативних дій. Спосіб їх приймання може бути важливим складником розуміння поведінки споживачів. У більшості рішень ефект від їх прийняття не пізнається безпосередньо, тобто не відразу зрозуміло, було прийняте добре чи погане рішення. Перевірка споживчих рішень проводиться у процесі споживання, використання товарів або користування послугами [8, с. 114]. Із погляду прийняття рішень споживача він бере участь у процесі вирішення проблеми, пов'язаної з альтернативним вибором товару [14, с. 48], тому суть прийняття рішень полягає у виборі конкретної дії.

Згідно з Ф. Котлером і Г. Армстронгом [10, с. 153], процес прийняття рішень споживачем складається з п'яти фаз: (1) відчуття потреби, (2) пошук альтернатив, (3) оцінка альтернатив, (4) рішення про купівлю, (5) відчуття після покупки. Не кожен споживач проходить усі етапи процесу прийняття рішень. Це залежить від того, що купує споживач, чи це раціональна покупка чи ні. Весь процес відбувається, коли споживач купує товар розкоші, статусний, дуже дорогий або такий, що рідко купується, наприклад автомобіль або будинок, тобто у разі раціональної покупки. Якщо споживач задоволений рішенням про придбання товару, а потім його використанням, є велика ймовірність того, що він знову купить такий самий товар. У цьому разі процес прийняття рішень обмежиться відчуттям потреби, рішенням про купівлю та відчуттями після покупки. У разі звичайних рішень споживач пропускає другий та третій етапи. Однак коли ціна товару, що купується, регулярно зростає, споживач знову вибиратиме з альтернатив.

Проаналізуємо дані етапи детальніше.

1. Перша фаза, тобто відчуття потреби, з'являється тоді, коли споживач відчуває нестачу чогось. Ця потреба може бути спровокована як зовнішнім, так і внутрішнім стимулом. Внутрішні стимули включають біологічні потреби організму, такі як їжа, вода, відчуття безпеки. Вони настільки термінові, що моментально призводять до дії. Потреби, стимульовані зовні, можуть бути викликані рекламою, виглядом товару. Потреба виникає тоді, коли споживач відчуває різницю між тим, що у нього $\epsilon$ зараз, і тим, що він хотів би мати, тобто ідеальним станом.

Ця невідповідність між існуючим і бажаним станом повинна бути достатньо великою і стосуватися досить важливої потреби людини. Можна виділити три різновиди такої невідповідності [12]:

1) відбувається зміна існуючого стану, наприклад в автомобілі закінчився бензин, притупилися бритви для гоління, перегоріла лампочка;

2) настає зміна бажаного стану, наприклад у результаті зміни моди змінилися покрій та колір ділових костюмів і потрібна заміна або оновлення гардеробу; 
3) настає зміна як існуючого, так і бажаного стану, наприклад коли поламався телефон, а на ринку з'явилася нова марка телефонів.

Відновлення балансу між реальним та бажаним станом є проблемою для споживача, яку він вирішуватиме. Він намагатиметься відновити рівновагу конкретними діями, спрямованими на усунення неприємного відчуття нестачі. Залежно від типу потреби вживаються певні кроки. Може статися так, що не кожна потреба викликає дію, іноді її інтенсивність занадто низька або не вистарчає ресурсів для ії задоволення [13, с. 199].

I роздрібні продавці, і виробники повинні стежити за тим, як змінюються споживачі, їхні проблеми та потреби. На те, як люди сприймають проблеми і шляхи їх вирішення, здатні впливати деякі сили, а саме сім'я, цінності, здоров'я, вік, дохід і референтні групи. Помічаючи зміни у цих змінних, ми часто відкриваємо нові маркетингові можливості. Тридцятирічні споживачі, які мають сім'ю, купують більше миючих засобів (зазвичай у великих упаковках), аніж сімдесятирічні споживачі, які живуть самотньо в квартирах меншої площі. У міру того як споживачі проходять різні етапи життя, їхні потреби і купівельні звички, найімовірніше, змінюватимуться у багатьох відношеннях. Окрім того, в очікуванні підвищення доходу зростають бажання споживача; саме тому Ford розсилає інформацію про Ford Focus та інші моделі студентам старших курсів університетів, які незабаром отримають свою першу високооплачувану роботу, але яких при цьому можуть зацікавити транспортні засоби з низьким споживанням палива [1, с. 117].

Розпізнання потреби - це також ідентифікація ситуації, у котрій одна потреба може бути задоволена широким набором товарів та послуг. Споживач починає шукати інформацію, щоб визначити набір альтернативних рішень, переходячи до другої фази процесу прийняття рішень.

2. Пошук альтернатив. Коли споживач відчуває потребу придбати товар або послугу, він стикається з необхідністю пошуку товару та послуги, за допомогою яких ця потреба буде задоволена [13, с. 198]. На думку дослідників маркетингу, пошук альтернатив $€$ найважливішим етапом прийняття рішення, оскільки саме у цей момент споживач вибирає товар і конкретну марку.

Пошук альтернатив зводиться до збору інформації, що стосується як різних можливостей вирішення проблеми (у сенсі вибору засобів і методів задоволення потреби), так і різних марок і типів, тобто варіантів задоволення потреби. Споживач може шукати інформацію як менш інтенсивним способом - через посилення уваги, так і більш ангажованим способом - шляхом активного пошуку інфор- мації. Ми розрізняємо два рівні ангажованості споживача у процес пошуку інформації про товар, що призводить до поділу на когнітивно ангажованого споживача (характеризується високою ангажованістю) та неангажованого споживача (характеризується низькою ангажованістю). Можна зробити висновок, що в умовах низької ангажованості споживач [5, с. 47] використовує доступну інформацію значно меншою мірою та, приймаючи рішення перед покупкою, не ґрунтується на раціональній обробці інформації. Зазвичай споживач із низьким рівнем ангажованості тестує продукт певного виду, щоб отримати інформацію про нього й оцінити його. Приймаючи рішення про купівлю, він керується переважно ситуаційними чинниками та джерелами інформації, наявними в місцях придбання. У разі значної ангажованості індивіда можна говорити про споживача, який [5, с. 44]:

- отримує інформацію з навколишнього середовища та інтерпретує ії відповідно до свого досвіду, поглядів, особистісних рис та суспільної позиції;

- шукає додаткову інформацію для уточнення виниклої потреби;

- проводить оцінку наявних конкуруючих видів, які могли б задовольнити потребу;

- формує переконання, ставлення та наміри, від яких залежить, чи зреалізує він покупку;

- діє під впливом внутрішніх психічних сил, купуючи та використовуючи товар.

Ключовими моментами зацікавлення на етапі прийняття рішень для підприємства $€$ основні джерела інформації та їхній вплив на подальші рішення щодо купівлі. Усі джерела інформації можна поділити на особисті джерела (сім'я, друзі, колеги, сусіди, знайомі), комерційні джерела (просування, менеджери з продажу, упаковка, виставки тощо), публічні джерела (засоби масової інформації (преса, радіо, телебачення, пошта, т. зв. пряма адресна пошта), організації споживачів) або практичний контакт із товаром (обслуговування, огляд, використання) [11, с. 180].

3. Останнім кроком перед рішенням про купівлю $є$ оцінка альтернатив. Після етапу пошуку та вибору всіх доступних альтернатив споживач аналізує ї та визначає критерії, якими буде керуватися під час відбору. Після того як споживач оцінить кожну з альтернатив відповідно до вибраних критеріїв, він інтегрує ці оцінки в єдину підсумкову оцінку, щоб вибрати одну найкращу. Ми говоримо тоді про стратегію прийняття рішення, тобто про стратегію вибору. Здійснюючи остаточний вибір, споживач намагається використати один із принципів вибору в купівельних ситуаціях. А. Фальковський і Т. Тишка [4, с. 139-142] описали шість найпростіших стратегій вибору: 
1) стратегія переваги позитивних характеристик - споживач порівнює позитивні характеристики товарів, які він хоче придбати, і вибирає товар із більшою кількістю таких характеристик;

2) об'єднювальна стратегія - заснована на виборі задовільного товару, не обов'язково найкращого. Споживач складає список характеристик, які він хотів би, щоб були в наявності у товарі, і перший, який буде відповідати усім вимогам зі списку, буде купленим;

3) альтернативна стратегія - також стосується вибору задовільного товару. Вона найчастіше застосовується, коли є якась спеціальна, унікальна можливість придбати даний товар. Ця стратегія полягає у виборі товару, який володіє хоча б однією важливою характеристикою;

4) лексикографічна стратегія - іï̈ основою $€$ створення ієрархії важливості ознак. Споживач аналізує товар із погляду найважливішої характеристики. Та альтернатива, яка домінує над іншими, негайно вибирається. Якщо ж існує кілька альтернатив, що мають цю найважливішу ознаку, споживач аналізує другу за важливістю ознаку, поки він не вибере альтернативу, що перевершує інші;

5) стратегія домінування та псевдодомінування - вона полягає у виборі тієї альтернативи, яка $є$ найкращою зі всіх і домінує над іншими альтернативами. На жаль, така ситуація виникає рідко. Тоді споживач послуговується стратегією псевдодомінювання, яка полягає у тому, що якщо певна річ нам подобається з погляду певних характеристик, то ми маємо схильність “силоміць» знаходити інші переваги, тобто переконувати себе, що дана приваблива альтернатива однозначно перевищує усі інші під кожним кутом зору. Однак такі маніпулювання власними оцінками може призводити до майбутніх розчарувань;

6) стратегія максимізації додаткової корисності МДК (стратегія компенсації) - базується на принципі, згідно з яким якась вада товару з погляду якоїсь однієї характеристики (наприклад, занадто висока ціна) може буде врівноважена його якоюсь перевагою з погляду якоїсь іншої характеристики (наприклад, висока якість).

4. Кульмінаційним етапом у процесі прийняття рішення про купівлю є сам етап прийняття рішення про купівлю. Тепер вибирається відповідна альтернатива залежно від запланованої покупки. Купівля - це функція наміру придбати та ситуації, в котрій знаходиться споживач. Вплив ситуації на прийняття рішення про придбання товару можна розглядати як мінімум у кількох вимірах, таких як фізичні умови (світло, звук, температура), суспільні умови (супроводжуючі особи, групові норми, поведінкові моделі), умови, що випли- вають із сутності ситуації (наприклад, причини покупки), час (наприклад, тиск часу), умови, що супроводжують акт самої покупки (наприклад, настрій, наявність готівкових коштів) та ін. [6, с. 75].

Згідно з Ф. Котлером, намір здійснити покупку виявляється також під впливом непередбачуваних чинників оточуючої дійсності. Намір формується на основі очікуваного сімейного доходу, очікуваної ціни товару й очікуваних вигід від його придбання. Непередбачувані чинники оточуючої дійсності можуть виникати раптово і змінити намір здійснити покупку в той самий момент, коли споживач уже був готовий до дії. Потенційний покупець може втратити роботу, може з'явитися нагальна необхідність у якійсь іншій покупці, хтось із його друзів може поділитися своїм розчаруванням у вибраному ним товарі [2, с. 172].

Здійснюючи покупку, споживач використовує різноманітні стратегії дії, які можна поділити на дві основні групи: оптимізаційні стратегії та спрощені стратегії. У випадку першої групи стратегій споживач оцінює кожну марку на основі всіх найважливіших для нього властивостей. Споживач, котрий використовує спрощені процедури, може звузити діапазон характеристик, які розглядаються, і зробити остаточний вибір лише на основі одного, найважливішого, критерію. Специфічною дією $є$ так звана покупка на пробу. Ї̈̈ використовують у разі купівлі конкретного товару або марки вперше, коли споживач хоче оцінити його через пряме споживання. Прийняття остаточного рішення не обмежується вибором товару чи конкретної марки. Воно тягне за собою ще багато рішень, таких як вибір місця придбання, час, спосіб оплати та кількість. Однак із погляду споживача ці рішення мають другорядне значення порівняно з основним рішенням про придбання товару.

5. Рішення про купівлю є кульмінацією дій, які здійснює споживач, але не означає, що воно завершує процес прийняття рішення про купівлю. Останнім етапом у цьому процесі $€$ відчуття після покупки, яке $є$ результатом порівняння між очікуванням покупки та здійсненням цих очікувань. Якщо досвід $є$ позитивним, буде велика ймовірність придбання такого ж товару або бренду знову, що в майбутньому спричинить спрощення та рутинізацію всього процесу прийняття рішень.

Споживач, незадоволений покупкою, поводитиметься зовсім по-іншому. Для нього це означає зміну стратегії придбання 3 метою виявлення різних альтернатив та розроблення різних критеріїв оцінки на основі вже набутого досвіду. За незадоволеності здійсненою покупкою з'являється стан психологічного дискомфорту, який називають післякупівель- 
ним когнітивним дисонансом. Когнітивний дисонанс - це різновид напруги чи тривоги, який ми відчуваємо, коли наша поведінка суперечить нашим поглядам або коли наші погляди несумісні між собою. Концепція когнітивного дисонансу випливає з теорії Фестінгера, який припускав, що люди відчувають потребу у внутрішній гармонії (консенсусі) між своїми установками, переконаннями та цінностями. Коли виникає невідповідність принаймні між двома елементами, то виникає ситуація неприємного внутрішнього напруження.

А.О. Хіршман [7] виокремлює два основні типи реакції споживачів на незадоволення від товару: відхід, тобто передусім утримання від повторної покупки даної марки, та словесна реакція, що полягає у поширенні негативних думок про дану марку. Дж. Антонідс та В. Ван Раай [3] також пропонують додати тут третю категорію - відсутність будь-якої реакції.

Цивілізаційні, технологічні та культурно-соціальні зміни також впливають на зміни типового процесу прийняття рішення про купівлю. Таким чином, упровадження роздрібної торгівлі великого формату, де самообслуговування $€$ домінуючою формою обслуговування клієнтів, збільшує кількість імпульсивних рішень. За оцінками, приблизно 80\% покупок у певних категоріях товарів та від 30\% до 50\% усіх покупок у сучасних формах роздрібних магазинів (гіпермаркети, супермаркети, дисконтні магазини) $є$ результатом імпульсивних рішень. Імпульсивним рішенням є скорочення або усунення окремих фаз закупівлі, таких як пошук альтернатив та їх оцінка.

Висновки 3 проведеного дослідження. Підсумовуючи викладені міркування, можемо стверджувати про важливість дослідження прийняття споживачем рішення про купівлю та чинників, які на даний процес впливають. Однак існують й інші чинники, які впливають на процес прийняття рішення про купівлю і не були предметом даного дослідження, напри- клад стать споживача, які ми маємо на меті дослідити у нашихподальших науковихпрацях.

\section{ЛІТЕРАТУРА:}

1. Блэкуэлл Р., Миниард П., Энджел Дж. Поведение потребителей / пер. с англ. ; 10-е изд. Санкт-Петербург : Питер, 2007. 944 с.

2. Котлер Ф. Основы маркетинга / пер. с англ. Москва : Ростинтэр, 1996. 704 с.

3. Antonides G., van Raaij W.F. Consumer Behaviour: A European Perspective. Chichester : John Wiley \& Sons Ltd, 1999. 642 p.

4. Falkowski A., Tyszka T. Psychologia zachowań konsumenckich. Gdańsk : Gdańskie Wydawnictwo Psychologiczne, 2003. 288 s.

5. Foxall G.R., Goldsmith R.E. Psychologia konsumenta dla menedżera marketingu. Warszawa : PWN, 1998. $285 \mathrm{~s}$.

6. Garbarski L. Zrozumieć nabywcę. Warszawa : PWE, 1994. 163 s.

7. Hirschman A.O. Exit, Voice and Loyalty: Responses to Decline in Firms. Organizations and States. Cambridge, MA : Harvard University Press. 1970. $176 \mathrm{p}$

8. Jachnis A. Psychologia konsumenta. Psychologiczne i socjologiczne uwarunkowania zachowań konsumenckich. Bydgoszcz-Warszawa : Oficyna Wydawnicza Branta, 2007. 411 s.

9. Janoś-Kresło M., Mróz B. (red.) Konsument i konsumpcja we współczesnej gospodarce. Warszawa : Oficyna Wydawnicza SGH, 2006. 296 s.

10. Kotler Ph., Armstrong G. Principles of Marketing. Prentice Hall, 8th ed., Upper Saddle River, 1999. 694 p.

11. Kotler Ph. Marketing. Analiza, planowanie, wdrażanie i kontrola. Warszawa : Gebethner \& Ska, wyd. I, 1994. 742 s.

12. Loudon D.L., Della Bitta A.J. Consumer Behavior: Concepts and Applications. McGraw-Hill International Editions, Fourth Edition. 1993. 788 p.

13. Rudnicki L. Zachowania konsumentów na rynku. Warszawa : Polskie Wydawnictwo Ekonomiczne S.A., 2012. $188 \mathrm{~s}$

14. Smyczek S., Sowa I. W: E. Kieżel (red.) Konsument i jego zachowania na rynku europejskim. Warszawa : PWE, 2010. 308 s. 